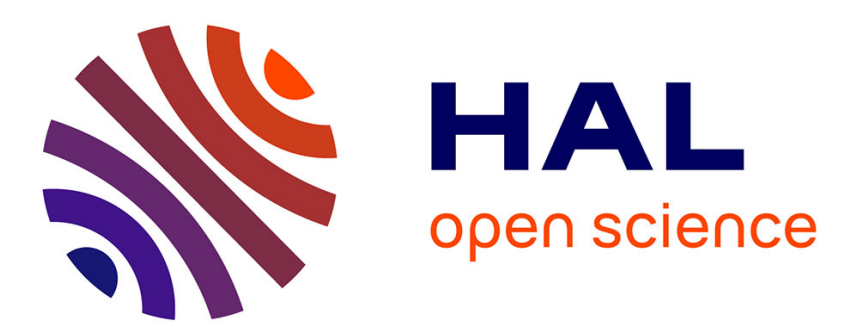

\title{
Mechanical response and dislocation substructure of high strength Ni-Cr-Mo steel subjected to impact loading
}

\author{
W. Lee, H. Lam
}

\section{- To cite this version:}

W. Lee, H. Lam. Mechanical response and dislocation substructure of high strength Ni-Cr-Mo steel subjected to impact loading. Journal de Physique IV Proceedings, 1994, 04 (C8), pp.C8-307-C8-312. 10.1051/jp4:1994846 . jpa-00253406

\section{HAL Id: jpa-00253406 https://hal.science/jpa-00253406}

Submitted on 1 Jan 1994

HAL is a multi-disciplinary open access archive for the deposit and dissemination of scientific research documents, whether they are published or not. The documents may come from teaching and research institutions in France or abroad, or from public or private research centers.
L'archive ouverte pluridisciplinaire HAL, est destinée au dépôt et à la diffusion de documents scientifiques de niveau recherche, publiés ou non, émanant des établissements d'enseignement et de recherche français ou étrangers, des laboratoires publics ou privés. 


\title{
Mechanical response and dislocation substructure of high strength $\mathrm{Ni}-\mathrm{Cr}$-Mo steel subjected to impact loading
}

\author{
W.S. Lee and H.F. Lam \\ Department of Mechanical Engineering, National Cheng Kung University, Tainan 70101, Taiwan, China
}

\begin{abstract}
Résumé
On étudie ici le comportement méchanique d'acier AISI 4340 soumis au chargement d'impact et la relation entre ses propriétés et l'aspect microstructural des dislocations. Les matériaux ont été trempés $\left(900^{\circ} \mathrm{C} / 30 \mathrm{~min}\right.$.) à l'huile et subi un revenu de 2 heures à $550^{\circ} \mathrm{C}$ avec l'arrêt à l'air afin d' obtenir une meilleure structure martensitique. Les propriétés dynamiques ont été déterminées à l'aide d'un dispositif de barre de Hopkinson en compression dans la gamme de vitesse de déformation allant de $10^{2} \mathrm{~s}^{-1}$ à $5 \times 10^{4} \mathrm{~s}^{-1}$. Les influences de la vitesse de défomation sur la caractéristique "contrainte-déformation", l'écrouissage et les mécanismes de déformation ont été présentées. De même, les échantillons déformés ont été analysés en microscope électronique à transmission dans le but d'observer le développement de cellules et de mesurer la densité des dislocations et la taille des cellules de dislocations. La relation entre la densité des dislocations, la contrainte d'écoulement et la vitesse de déformation ont été discutées en fonction de la structure des dislocations observée.
\end{abstract}

\begin{abstract}
This work focuses on investigating the mechanical response of high strength $\mathrm{Ni}-\mathrm{Cr}-\mathrm{Mo}$ steel (AISI 4340) subject to impact loading, and the relation between its properties and its dislocation substructure. The material was quenched $\left(900^{\circ} \mathrm{C} / 30 \mathrm{~min}\right.$.) in oil and then tempered at $550^{\circ} \mathrm{C}$ for 2 hours to obtain a better tempering martensite structure. The high-strain-rate properties are determined by a series of standard split Hopkinson compression tests at strain rate ranging from $10^{2} \mathrm{~s}^{-1}$ to $5 \times 10^{4} \mathrm{~s}^{-1}$. The influences of the strain rate on the stress-strain characteristics, work hardening and deformation mechanisms are discussed. Parallel with this work, the deformed specimens are studied with transmission electron microscopy techniques to observe the development of a cell structure and measure the dislocation density and cell size. The relationships between dislocation density, flow stress, and strain rate have been described in terms of the dislocation structure observed.
\end{abstract}

\section{INTRODUCTION}

The mechanical response of metals is used to be studied under a variety of regimes for many important practical applications such as forming, machining, punching, and armor penetration. Because of the potential wide ultilization of AISI 4340 alloy steel in the machine part-members, deformation modes under different temperatures, strain levels and strain rates are of great concern. The problem is that if this material is accidentally subjected to any impact loading, its deformation modes and damage conditions may be drastically distinct from those under low rate deformation. Therefore, it is very important to study its mechanical properties under high strain rate conditions.

Advanced techniques for carrying out high strain rate tests have been developed $(1,2)$ and the experimental results have been discussed from both macroscopic and microscopic aspects $(3,4)$. In reviews 
$(5,6)$ of recent articles it has been demonstrated that dynamic loading and temperature strongly influence the strength of a variety of metals and alloys and that the effects of strain rate and temperature on the mechanical properties of metals can be characterized in four different regions corresponding to different strain rate ranges $(7,8)$. On a phenomenological point of view, the results mentioned above allow to determine some characteristic parameters of the high strain rate behaviour of metals, like strain, temperature, stress and strain rate sensitivities. These parameters can then be used in constitutive equation in the field of dynamic plasticity and may be related to different rate controlling mechanisms $(9,10)$ which are active during the high rate deformaion .

On the other hand, during the plastic deformation, the mechanical response of a material depends on its current microstructure at the dislocation level, furthermore, the changes in microstructure result in changes of the mechanical behaviour. Hence, in order to construct a constitutive law incorporating microstructure and micromechanics into the continuum description of plastic deformation, the mechanical studies must be supported by structural studies of the dislocation substructure generated at different strain rates. Past and recent researches both have indicated that dislocation densities and configurations after dynamic loading show an increase in strengthening properties $(11,12)$. Chiem and Duffy (13) and more recently Lee (14) found that in $\mathrm{Al}$ and $\mathrm{W}$ single crystals the dislocation densities increased with an increase in strain rate up to $5 \times 10^{3} \mathrm{~s}^{-1}$. Actually, the formation of the cell structure of dislocations depends not only on the strain and strain rate levels but also on the stacking fault free energy of metals.

In this paper, the deformation characteristics and the corresponding constitutive equation for AISI 4340 alloy steel deformed under impact loading conditions are presented. The microscopic observations of dislocation configurations and densities are also described and discussed in terms of macroscopic response.

\section{EXPERIMENTAL PROCEDURE}

A rolled bar of AISI 4340 high strength alloy steel was used in this investigation. The material was quenched in oil $\left(900^{\circ} \mathrm{C} / 30 \mathrm{~min}\right)$ and then tempered at $550^{\circ} \mathrm{C}$ for $2 \mathrm{hrs}$ in order to produce the tempering martensite structure with precipitated alloy carbides. This microstructure has been characterized and examined in our earlier paper (15). After heat treatment, cylindrical compressive specimens were cut in the longitudinal orientation from the rolled bar and polished to a final size of $10 \mathrm{~mm}$ long by $10 \mathrm{~mm}$ in diameter.The mechanical tests were performed on a split Hopkinson bar loaded in compression. The specimens have been deformed within the strain rate range of $10^{-4}$ to $10^{3} \mathrm{~s}^{-1}$ and the strain range of $5 \%$ to $20 \%$ at room temperature. Fig. 1 shows schematically the test set-up and control block diagram. Being based on the elementary one dimensional elastic wave propagation theory, the stress, strain and strain rate of the specimens can be calculated from the relations as described by Lindholm(16). After mechanical testing, the dislocation configurations were examined by transmission electron microscopy. The slices parallel to the impact surfaces with thickness $0.5 \mathrm{~mm}$ is spark wire cut from each deformed specimens and is thinned by granding on 1200 grade silicon carbide emery paper to a thickness appropriate for jet thinning. Discs of $3 \mathrm{~mm}$ in diameter were then trepanned from these slices by electron discharge machining. The thin foils suitable for transmission electron microscopy were obtained by chemical polishing with a circulating electrolyte composing of $95 \%$ perchloric and $5 \%$ acetic acid in a twin jet electropolisher (Tenupol 3) maintained at $0^{\circ} \mathrm{C}$. The window technique was used to make the final perforation in the jet thinned samples. A Hitachi H-700H STEM operated at $175 \mathrm{KV}$ was used for the TEM study.

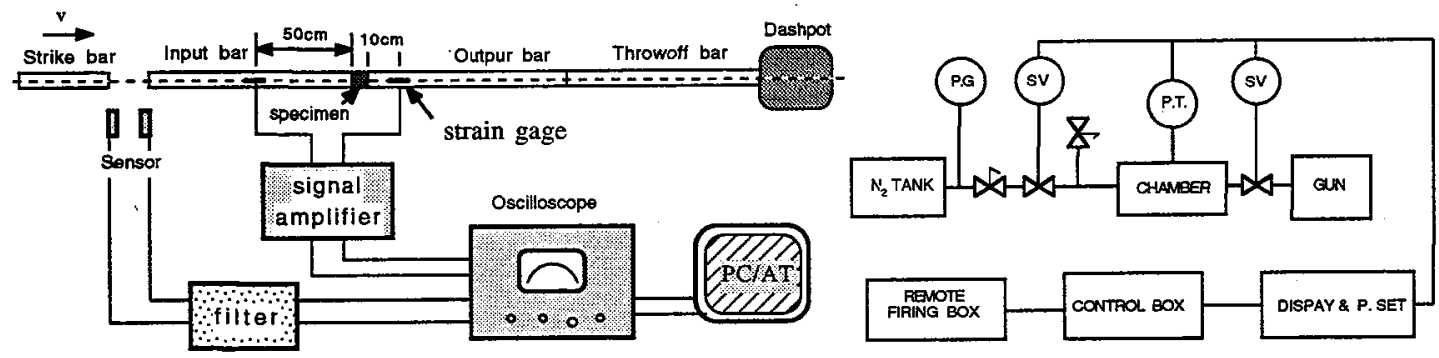

Fig. 1: Schematic diagram of the experimental set-up and the control system.

\section{RESULTS AND DISCUSSION}

\subsection{Deformation Behaviour}

Typical true stress-strain curves for AISI4340 steel deformed at various strain rates are shown in Fig.2. It is noticeable that the dynamic curve shows a distinct strain rate effect when compared to lower rate 
curves. The average flow stress being raised by between 500 to $650 \mathrm{MPa}$ as the strain rate is increased from $\dot{\varepsilon}=0.02 \mathrm{~s}^{-1}$ to $4400 \mathrm{~s}^{-1}$. In the low strain rate range between $0.02 \mathrm{~s}^{-1}$ and $1 \mathrm{~s}^{-1}$, the yielding stress ( $\varepsilon$ $=0.2 \%$ ) is a weak function of strain rate and increases slightly from $850 \mathrm{MPa}$ to $920 \mathrm{MPa}$. However, as the strain rate increases in the high strain rate range, the yielding stress increse rapidly from about $1000 \mathrm{MPa}$ for strain rate level of $500 \mathrm{~s}^{-1}$ to $1450 \mathrm{MPa}$ for $4400 \mathrm{~s}^{-1}$. Comparing the yielding behaviour of quasi-static with that of dynamic loading, the yielding stress of the latter is more sensitive to the strain rate than the former. Also, the relationship between flow stress and strain for each strain rate can be described by Hollomon's law $\sigma=K \varepsilon^{\mathrm{n}}$ with different material constant $\mathrm{K}$ and work hardening exponent $\mathrm{n}$. From Table 1, we can find that the material constant $\mathrm{K}$ increases directly while the work hardening exponent $\mathrm{n}$ varies inversely with strain rate. However, it should be pointed out that the work hardening rate in dynamic curves is also higher than that of quasi-static curves. This effect is propably caused by an increase of the dislocation multiplication rate with strain and strain rate during deformation processes.

Table 1: Material constant $\mathrm{K}$ and work hardening exponent $\mathrm{n}$ as a function of strain rate.

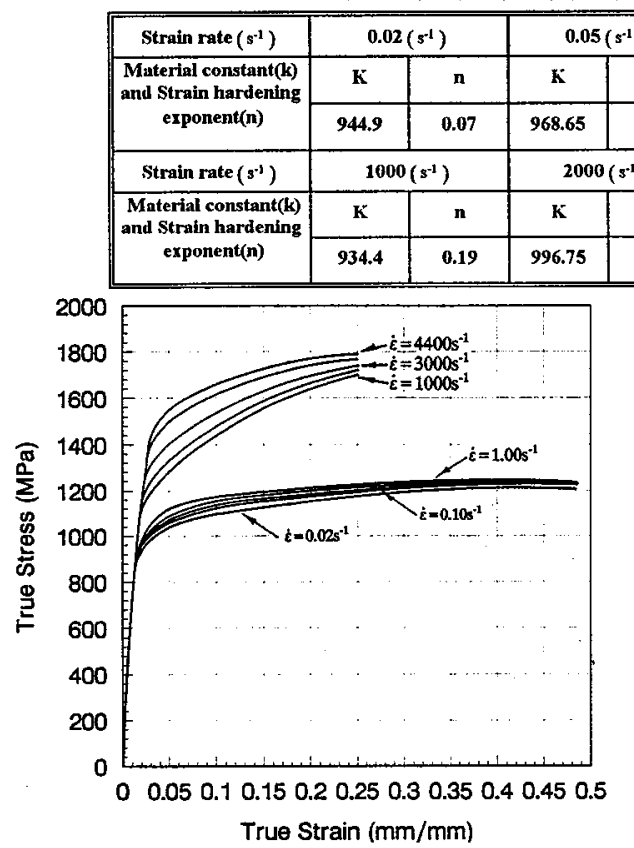

Fig. 2: True stress-strain curves of high strength $\mathrm{Ni}-\mathrm{Cr}-\mathrm{Mo}$ steel under different strain rates.

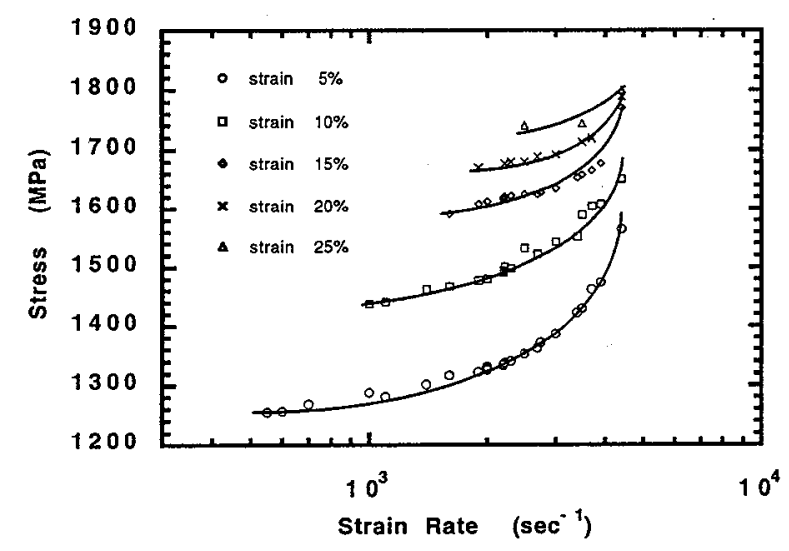

Fig. 3: The influence of strain rate in the flow stress at various plastic strain.

\subsection{Effect of Strain Rate}

As shown in Fig. 3, the stress-strain data obtained from Fig.2 in dynamic strain rate range can be presented in plots of stress against log strain rate for different values of constant strain. The flow stress increases immediately with increasing strain rate and a sudden dramatic increase of flow stress occurs when strain rates approach the range of $10^{3} \mathrm{~s}^{-1}$ to $5 \times 10^{3} \mathrm{~s}^{-1}$. The slopes of these curves indicate clearly the degree of rate sensitivity of this material. The sudden increase in strain rate sensitivity at high strain rate can be interpreted as a change in the rate-controlling deformation mechanism. As the strain rate range is lower than about $10^{3} \mathrm{~s}^{-1}$, the dominant rate controlling mechanism for dislocation motion is a thermally aided cutting of localized extrinsic obstacles. When the strain rate is higher than about $10^{3} \mathrm{~s}^{-1}$, it is thought that the thermal activation is no longer necessary to assist a dislocation past a barrier. The dislocation motion becomes continuous and the dislocation velocity is solely limited by drag mechanisms.

The effects of strain rate on the microhardness of AISI 4340 steel are also shown in Fig. 4. As expected, the microhardness increases systematically with both strain and strain rate due to the work hardening and dislocation multiplications. In addition to know that the microhardness increases apparently as a function of the increasing strain rate, it is more interesting to note that the effect of strain rate on microhardness is more distinct than that of strain.

According to traditional analysis, the strain rate sensitivity may be defined as : $\beta=\left[\partial \sigma / \partial \ln \left(\dot{\varepsilon}_{1} / \dot{\varepsilon}_{2}\right)\right]=$ $\left(\sigma_{1}-\sigma_{2}\right) / \ln \left(\dot{\varepsilon}_{1} / \dot{\varepsilon}_{2}\right)$. By means of this equation and the data of Fig.3, the strain rate sensitivity as a 
function of plastic strain is presented in Fig. 5 in four different strain rate regions. It is evident that strain rate sensitiviy obtained at higher strain rate regions is greater than that at lower strain rate region under plastic deformation from $5 \%$ to $25 \%$. In strain rate region between $10^{3} \mathrm{~s}^{-1}$ and $2 \times 10^{3} \mathrm{~s}^{-1}$, comparing with different plastic deformations, the strain rate sensitivity has a slight decrease from $55 \mathrm{MPa}$ to $22 \mathrm{MPa}$ but no obvious dependence on plastic deformation. The coefficient $\beta$ in this strain rate region is the lowest of the four strain rate regions tested. If the strain rate increases in the region between $2 \times 10^{3} \mathrm{~s}^{-1}$ and $3 \times 10^{3} \mathrm{~s}^{-1}$ and the region between $3 \times 10^{3} \mathrm{~s}^{-1}$ and $4 \times 10^{3} \mathrm{~s}^{-1}$, the strain rate sensitivity decreases dramatically with plastic deformation. While enhancing the strain rate to the region between $4 \times 10^{3} \mathrm{~s}^{-1}$ to $4.4 \times 10^{3} \mathrm{~s}^{-1}, \beta$ decreases with plastic deformation again and is the most active range to the variation of plastic deformation among the four. It's worth of noting that in each strain rate region, the rate sensitivity decreases remarkablely as accumulated plastic strain is larger than $20 \%$. This may be explained by the microstructure changes and the competition between the rate of work hardening and the rate of thermal softening during deformation processes.

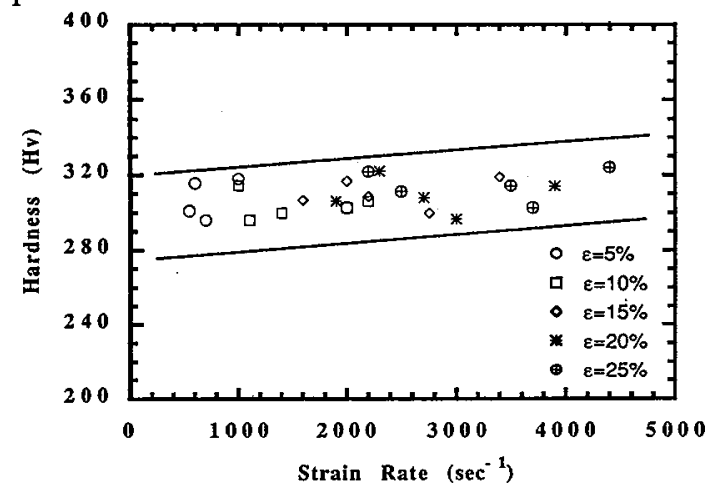

Fig. 4: Plots of the microhardness against the strain rate for various deformation strain.

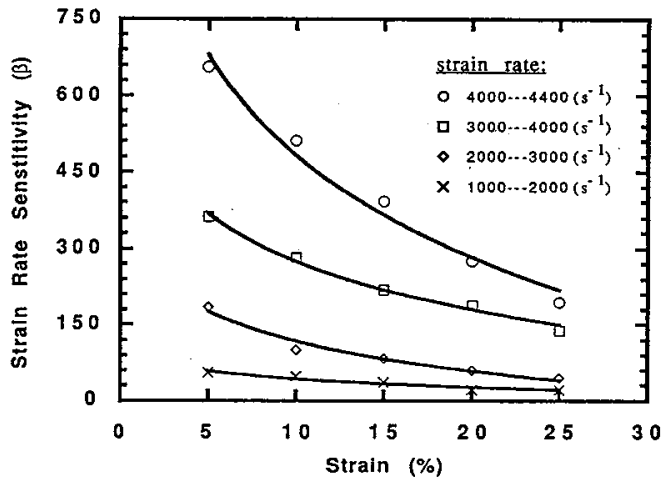

Fig. 5: The variations of strain rate sensitivity as a function of plastic strain.

\subsection{Estimation of Thermal Activation Volume}

The parameter of strain rate sensitivity $\beta$ may be used to calculate the activation volume $\mathrm{v}^{*}$ under the assumption that the deformation mechanism is thermally activated and that the activation free energy $G$ is a linear function of the applied stress. Under these conditions, the activation volume is given by $\mathrm{v}^{*}=\mathrm{KT}\{$ $\ln \left(\dot{\varepsilon}_{1} / \dot{\varepsilon}_{2}\right) /\left(\sigma_{1}-\sigma_{2}\right\}=\mathrm{KT} / \beta$, where $\mathrm{K}$ is the Boltzmann's constant and T is the temperature in degree absolute.

Fig. 6 shows the thermal activation volume $\mathrm{v}^{*} / \mathrm{b}^{3}$ as a function of plastic deformation for four tested strain rate regions, in which the Burgers vector $b$ for AISI 4340 steel is $2.25 \mathrm{~A}^{\circ}$. It appears that the thermal activation volume decreases obviously with increasing strain rate due to an increase in dislocation density. when considering the variation of activation volume for the plastic deformation, it is found that in all strain rate regions, the activation volume increases with increasing plastic deformation. Also, at strain rate below $3 \times 10^{3} \mathrm{~s}^{-1}$, the values of activation volume vary from 1 to 8 and the predominant deformation mechanism may be as dislocation climb mentioned by CONRAD (17). However, as the strain rate range is higher than this range, so the values of $v^{*} / b^{3}$ obtained lie below 1 . This alteration in the activation volume can be taken to justify that the deformation mechanism is changed from thermal activation to viscous damping of dislocations.

\subsection{Constitutive Equation}

From the stress-strain curves obtained at different strain rates test, the relationship between stress and strain can be presented in plot of $\ln \sigma$ against $\ln \varepsilon$ to compare with the simulation results of the constitutive equation proposed in the form of $\sigma=\mathrm{A}+\mathrm{B} \varepsilon^{\mathrm{n}}+\left[\ln \left(\dot{\varepsilon} / \dot{\varepsilon}_{\mathrm{o}}\right)\right]^{\mathrm{D}}$, where A represents a constant, often an elastic part or yielding strength; $B$ is a propotional factor; $\varepsilon$ is the plastic deformation; $n$ is the strain hardening exponent; $\dot{\varepsilon}$ is the tested strain rate; $\dot{\varepsilon}_{0}$ is the strain rate where its sensitive effect begins to show; and $\mathrm{D}$ is the parameter which depends on strain rate sensitivity.

The values of $A, B$ and $n$ were determined by curve fitting using the stress-strain curves at tested strain rate range. In this case, the values of $A=1120 \mathrm{MPa}, \mathrm{B}=46 \mathrm{MPa}, \mathrm{n}=0.74, \mathrm{D}=1.96$ and $\dot{\varepsilon}_{0}=10^{-5} \mathrm{~s}^{-1}$ 
are chosen to describe the deformation behaviour. By using these constants to the constitutive equation, the simulation also shows stress-strain relation for different strain and strain rate levels, analogous to the data obtained in the Split- Hopkinson bars test. In other words, the experimental results of the high strain rate tests agreed well with the predicted constitutive equation, see Fig. 7. Besides, this result also indicated that the form of this equation can be used to simulate a variety of high strain rate behaviours of metals simply by previously deciding these parameters through certain high strain rate tests.

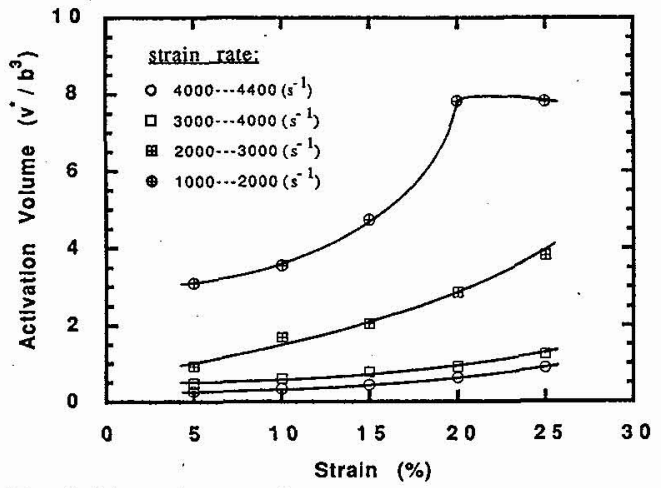

Fig. 6: The variations of activation volume as a function of plastic strain.

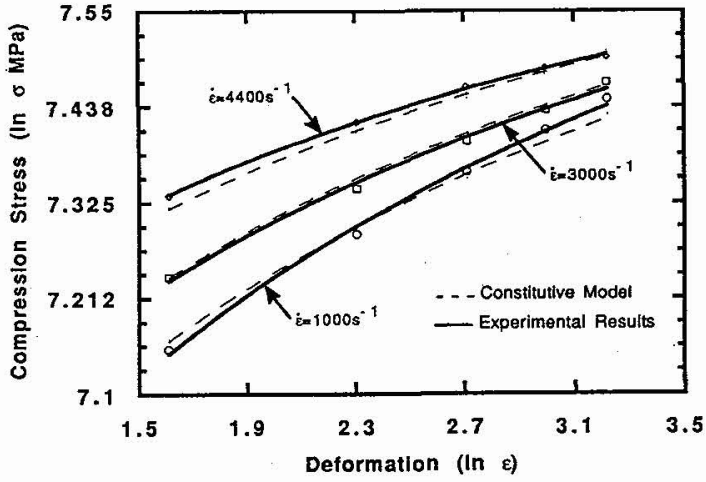

Fig. 7: Compression stress versus total deformation in ln-ln plot.

\subsection{Microstructural observations}

The micrographs of Figs. 8 to 9 show the typical microstructure at fixed strain of $20 \%$ deformed at different strain rate levels. In these loading conditions, the dislocation density, involving different Burgers vector, is very high. As the specimens deformed at the strain rate of $5 \times 10^{2} \mathrm{~s}^{-1}$, Fig. 8 (a), the carbide precipitates distribution and dislocation arrangements are often non-uniform. Many dislocations are pinned by the carbide precipitates and cross each other to develop and form the dislocation cells due to the relatively high stacking fault energy which aids cross slip of dislocation during deformation. In this strain rate condition, the cell walls are wide and the cells are not clearly defined.

By increasing the strain rate up to $10^{3} \mathrm{~s}^{-1}$, Fig. $8(\mathrm{~b})$, the dislocation cells are very distinct with thin walls. The substructure observed consists of closely-tangled dislocation cells interspersed with a number of dislocation loops in the cell interiors and cell walls. The dislocation density is also higher than that deformed at $5 \times 10^{2} \mathrm{~s}^{-1}$. As the strain rate is increased above $2 \times 10^{3} \mathrm{~s}^{-1}$, Fig. 9 (a), the dislocation cells also appears on the substructure, however, the cell walls are found to be more well-defined in appearence. Many individual dislocations and dislocation loops can also be resolved within the cell walls. By comparing Fig. 9 (a) with Fig. 8 (b), it is evident that strain rate play a key role in the final configuration of dislocations. The dislocation density and cell wall increase considerablely with strain rate. In addition, the decrease in dislocation cell size results in increasing the strain hardening rate and flow stress.

Finally, when specimens are deformed at $4.5 \times 10^{3} \mathrm{~s}^{-1}$, Fig. 9 (b), a high density of small dislocation cells is observed. This substructure suggest again that increment in strain rate tends to increase significantly the dislocation density and that increase of flow stress, observed in Fig. 2, is related to the dislocation cell reduction as well as the associated increase in dislocation density.
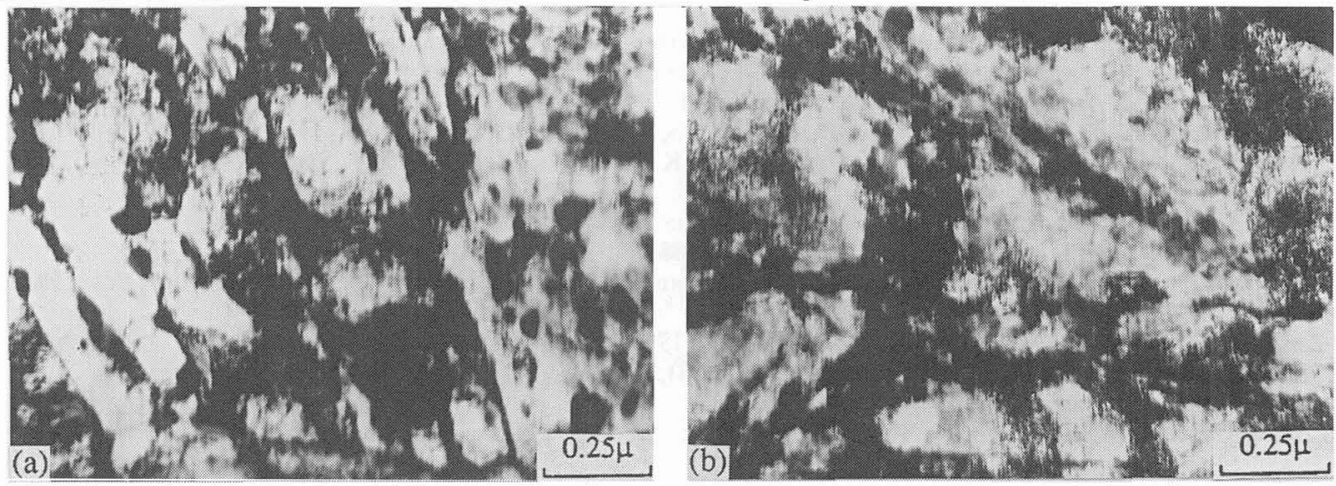

Fig. 8: Dislocation substructure of specimens deformed at (a) $\dot{\varepsilon}=5 \times 10^{2} \mathrm{~s}^{-1}$ and (b) $\dot{\varepsilon}=1 \times 10^{3} \mathrm{~s}^{-1}$. 

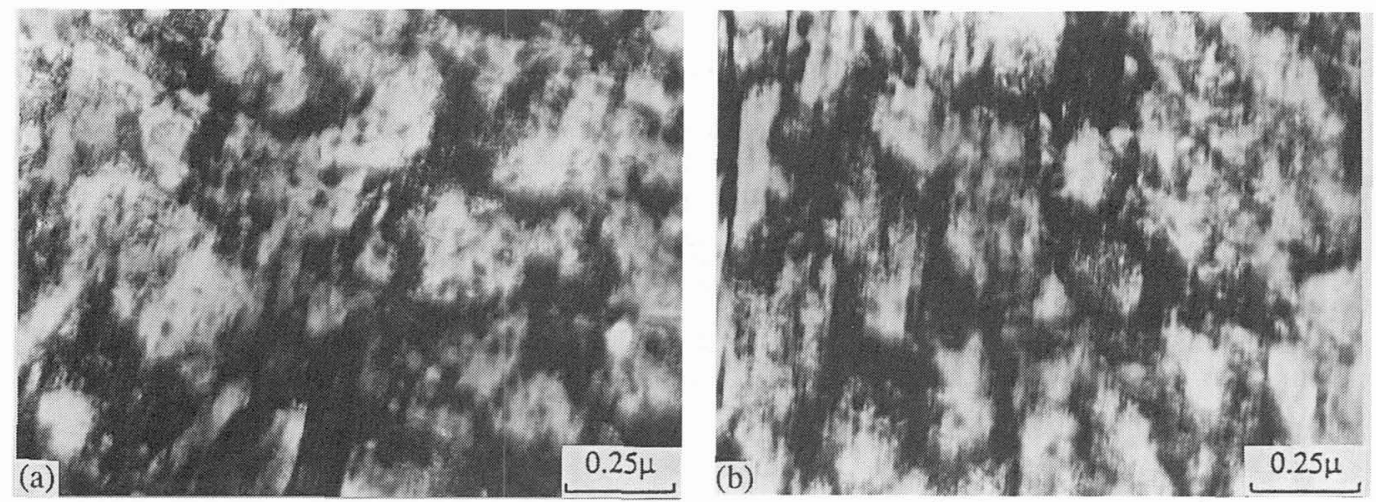

Fig. 9: Dislocation substructure of specimens deformed at (a) $\dot{\varepsilon}=2 \times 10^{3} \mathrm{~s}^{-1}$ and (b) $\dot{\varepsilon}=4.5 \times 10^{3} \mathrm{~s}^{-1}$.

\section{CONCLUSIONS}

The mechanical response and microstructure evolution of AISI 4340 steel under different strain rate conditions have been studied. The stress-strain response shows that this material is quite sensitive to strain rate. The flow stress and residural microhardness increase directly while work hardening exponent inversely with increased strain rate. As strain rate is less than $10^{3} \mathrm{~s}^{-1}$, the deformation is mainly controlled by thermally activated mechanism. However, when the strain rate is larger than $10^{3} \mathrm{~s}^{-1}$, a different mechanism based on viscous dislocation motion becomes dominant. For the microstructural analysis, TEM observation reveals that the dislocation characteristics depend on the strain and strain rate levels. The dislocation densities increased with an increase in strain rate. The reduction of the dislocation cell size results in the increase of the flow stress. Based on the dynamic stress-strain results, a deformation constitutive equation incorporating the effects of work hardening and strain rate sensitivity of this material has been proposed. The numerical simulations are verified by experimental data, and the results are quite satisfactory.

\section{Acknowledgement}

This work is supported by National Science Council, R.O.C. under contract No. 83-0401-E-006147. The mechanical testing is performed in the laboratory of structure mechanics of Department of Aeronautics and Astronautics and is gratefully acknowledged. The authors would also like to thank Mr. F. Y. Huang and Mr. S. Y. Yaor for the experimental contributions.

\section{REFERENCES}

[1] Staker, M. R., in Metals Handbook, 9th ed., Vol. 8, Mechanical Testing, American Sociiety for Metals, Metals Park (1985) 185-297.

[2] Sierakowski, R. L., in Dynamic constitutive/Failure Models, AFWAL-TR-88-4229, Wright-Patterson Air Force Base, OH (1985).

[3] Hardeing, J., in Material at High Strain Rates, (T. Z. Blazynski, Ed.), Elsevier Applied Science, New York (1987), 133-186.

[4] Grady, D. E. et al., in Material behaviour Under High Stress and Ultrahigh Loading Rates (J. Mescall and V. Weiss, Eds.), Plenum, New York (1983), 81-100.

[5] Rajendran, A. M., and S.J. Bless, AFWAL-TR-88-4229, Wright-Patterson Air Force Base, OH (1985).

[6] Asay, J. R., and G. I. Kerly, Int. J. Impact Engng, 5 (1987) 69-99.

[7] Meyer, L. W., and E. Staskewitsch, in Impact Loading and Dynamic Behaviour of Materials (C. Y. Chiem, H.-D. Kunze, and L. W. Meyer, Eds.), DGM Informationsgesellschaft, Oberursel, West Germany (1988), 331-342.

[8] Lindholm, U. S., in High Velocity Deformation of Solids (K. Kawata and J. Shiori, Eds), Springer-Verlag, New York (1978), 26-35.

[9] Nicolas, T., in Impact Dynamics (J. Zukas et al., Eds.), Wiley, New York (1982), 277-332.

[10] Follansbee, P. S., and U. F. Kocks, Acta Metall., 36 (1988), 81-93.

[11] Murr, L. E., in Shock Waves and High Strain Rate Phenomena in Metals ( M. A. Meyers and L.E. Murr, Eds.), Pleum, New York (1981), 607-673.

[12] Zerilli, F. J., and R. W. Armstrong, J. Appl. Phys., 61 (1987), 1816-1825.

[13] Chiem, C. Y., and Duffy, J., Mat. Sci. Engng., 57 (1883),233-247.

[14] Lee, W. S., Ph. D. Thesis, June 1990, Nantes, France.

[15] Lee, W. S., and Wt, T. B., Proc. of The 1993 Annual Conf. of The Chinese Soc. for Mat. Sci., Hsien-Chou, April (1993), 1131-1139.

[16] Lindholm, U. S., J. Mech. Phys. Solids, 12 (1964), 317.

[17] Conrad, H. , J. Metals, 16 (1964), 582. 